\title{
Debris flow research in Russia and the Former Soviet Union: history and perspectives
}

\author{
K. N. Nosov ${ }^{1}$, S. S. Chernomorets ${ }^{2}$, O. V. Tutubalina ${ }^{2}$ \\ \& E. V. Zaporozhchenko ${ }^{1}$ \\ ${ }^{I}$ Sevkavgiprovodkhoz Institute, Pyatigorsk, Russia \\ ${ }^{2}$ Moscow State University, Faculty of Geography, Russia
}

\begin{abstract}
Studies of debris flows in the Russian Empire started in the 1860s. At that time expeditions were organized to study the ice-rock collapses that were blocking the trans-Caucasian road. In 1859 B. Statkowsky introduced the term sel' (debris flow), an Arabic word current among nations of the Caucasus. Later debris flows were studied in the Caucasus, the Carpathians, the mountains of Central Asia and Siberia, in Kamchatka Peninsula etc. Debris flow conferences were organised by experts from Kazakhstan, Georgia, Russia, Armenia, Ukraine, Azerbaijan, Kyrgyzstan and Tajikistan (24 conferences in 1949-1982). The late 1950-80s were "the golden thirty years" of the Soviet debris flow science. A strong school of experts worked in ministries, institutes, universities and hydrometeorological service. A Debris Flow Commission was established for co-ordination of all activities. Following a number of disastrous debris flows, manuals for monitoring debris flows were written. Various protective infrastructures were built. The collapse of the USSR (1991) has divided the debris flow community by the new state boundaries. The economic crisis of the 1990s hit hard, and only now this science is reactivated due to large debris flow disasters of the early $21^{\text {st }}$ century in the Caucasus. Three conferences have been organised. In 2005, the Debris Flow Association (DFA) was established in Russia as a professional society of experts (http://www.rsk.land.ru/index_eng.htm). It has now been joined by members from other countries. A Russian debris flow bibliography for 1968-2005 is being prepared for publication. The DFA plans to organise an international debris flow conference in Russia in 2008.

Keywords: debris flow, mudflow, Russia, Former Soviet Union, research.
\end{abstract}




\section{Introduction}

Sometimes it happens that a whole period of learning and knowledge sinks into oblivion. For a long period a phenomena is intensively studied, but then hard times come and the tradition is lost. Later a new generation comes and starts all over again. This is a story of debris flow research in Russia and the countries of the former Soviet Union.

Decades of research within a large unified country, and generations of experts contributed to development of selevedenie, the Soviet debris flow science. Then the USSR was dissected by boundaries of the new states, and opportunities for collaboration diminished. Research programmes aimed at a systematic approach within large state-funded projects were replaced by smaller national studies. In several countries the debris flow problem kept its priority, in others it was no longer considered important. The economic crisis of the $1990 \mathrm{~s}$ has abruptly reduced research funding. Multi-year observation sequences were stopped. Many researchers had to seek jobs outside science.

The goal of this paper is to recall the previous experience, follow the main development stages of the debris flow science and assess the contemporary state of the field. The authors are engaged in debris flow research, mainly in the Caucasian mountains, and have published several dozen articles on the related topics.

We are not the first to attempt such a review, but follow earlier examples of Bogolyubova [1], and Fleishman [2]. However, the progress in recent decades has not been assessed, while the situation has changed significantly and shall be analysed. Moreover, previous reviews were published in Russian and were not accessible for an international reader.

The Russian debris flow literature numbers some 5,500 works. The volume of this paper does not allow listing even all of the most important studies, so the references are limited out of necessity.

The preparation of this article also involved a review of some historical sources, not related to the Russian debris flow science. It enabled to follow the earliest impacts of debris flows on the population of mountains.

\section{When the humankind first encountered debris flows?}

In all probability, it happened when people started to build homes and roads in mountains.

Homer [3], in $8^{\text {th }}$ century BC, wrote in the Iliad: “...fill your streams with water from their sources, rouse all your torrents to a fury; raise your wave on high, and let snags and stones come thundering down you that we may make an end of this savage creature who is now lording it as though he were a god". The Bible also mentions debris flows several times. E.g. in Job [4] we read: "Who has the wisdom to count the clouds? Who can tip over the water jars of the heavens when the dust becomes hard and the clods of earth stick together?" In the same book [5] we also read: "But as a mountain erodes and crumbles and as 
a rock is moved from its place, as water wears away stones and torrents wash away the soil, so you destroy man's hope".

Some of the debris flow dates are recorded in ancient sources. E.g., in $79 \mathrm{AD}$ in Italy during the eruption of Vesuvius, described by Pliny the Younger [6] a volcanogenic debris flow formed and covered the streets of the town of Herculanum.

The Roman philosopher Seneca [7] wrote in $1^{\text {st }}$ century AD about a future debris flow disaster which could happen (in modern terms) under joint action of an earthquake, a tsunami and an extreme rain. As a result of increased wetness, the earth would crumble, and rot, then spread about as a liquid mud. Then rivers will emerge from the mountains and shake the mountains by their mighty force, then flow further, spilling over the banks.

Inhabitants of the mountainous Caucasus experienced debris flows from time to time, and consequently the national epic mentions large stones carried by water. E.g. in the Georgian epic about the Knight in the Panther's Skin (12 ${ }^{\text {th }}$ century) recorded by Rustaveli [8] we read: "The stones stepped out of the river, weeping". The medieval Nart sagas describe how the Kuban River breaches its banks "moving about and tumbling stones size of a house, the stones collide, we hear rattle and thunder" [9].

In $16^{\text {th }}$ century Leonardo da Vinci [10] referred to the indescribable damages brought by the mountain rivers breaching their banks.

As for the scientific studies of debris flows, it is customary to list the works of Fabre [11] and Surrel [12] as some of the first in Europe.

\section{The Georgian Military Road and the beginning of Russian debris flow studies}

The way crossing the Caucasian mountains through the valleys of Aragvi and Terek Rivers has been known for several millennia. In 1 century BC the Roman geographer Strabo [13] wrote: "From the Nomades on the north there is a difficult ascent for three days, and then a narrow road by the side of the river Aragus, a journey of four days, which road admits only one person to pass at a time (p. 231). Pliny the Elder [14] in the $1^{\text {st }}$ century AD noted: "After passing the last, we come to the Gates of Caucasus, by many persons most erroneously called the Caspian Passes; a vast work of nature, which has suddenly wrenched asunder in this place a chain of mountains. At this spot are gates barred up with beams shod with iron, while beneath the middle there runs a stream which emits a most fetid odour" (p. 2021-2022).

In early $19^{\text {th }}$ century the South-Caucasian lands were added to the Russian Empire. The only way through the Caucasus range was the ancient road through Aragvi and Terek. As the traffic grew, the road was improved, fortified and named the Georgian Military Road. The Russian poet Pushkin [15] wrote about this place in 1829: "Here rivers are born that tear mountain asunder and landslides begin with a crash as of thunder".

In that period Russian military and civil authorities faced the problem of disasters, caused by the Devdorak glacier on the slope of Mt. Kazbek. Each time 
after the ice-debris flows and ice blockages on the road (registered in 1776, 1778, 1785, 1808, 1817 and 1832) the traffic along the Georgian Military Road was interrupted for a long period of time. These disasters were a subject of detailed scientific study by the commission of Boleslav Statkowsky (fig.1). He organised the first debris flow expeditions in the Russian Empire. In 1859 г. Statkowsky [16] introduced a term sel' (debris flow). In a later paper in 1997 he writes: "Let me describe one astonishing phenomena which is not rare in the mountains, the phenomena which no protective structures can withstand, and which is commonly named discharge or sel in the Caucasus, while in the Alps it is called Nante, Nante sauvage and cone de dejection. Usually these follow a thunderstorm in the mountains, when certain gullies, which have favourable location, eject great masses of rocks, stones, and mud. These entrain everything on their way, and stop the transportation on the roads, sometimes for a long period of time" (Statkowsky [17]).

The current meaning of the term sel' in Russia includes both debris flows и mudflows.

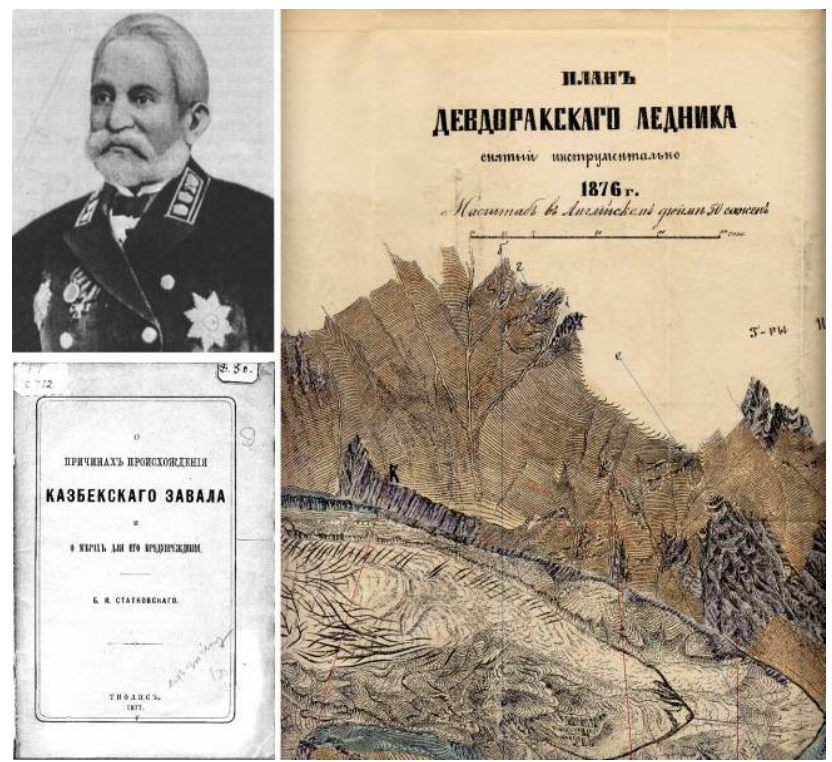

Figure 1: $\quad$ Top left: B.I. Statkowsky (1825-1898), a pioneer of Russian debris flow science. Lower left: cover of one of the Statkowsky's books. Right: part of the map of Devdorak Glacier, showing the areas where the disasters were formed, after Statkowsky [17].

In late $19^{\text {th }}$ - early $20^{\text {th }}$ century, experiments on forest planting for debris flow protection were conducted in the Caucasus (B.N. Lisnevsky) and in Central Asia (S. Yu. Rauner). Consequences of several debris flows were studied (M.P. Psarev, K.I. Bogdanovich). 
Catastrophic debris flows attracted attention of the experts in the Soviet Union, the state formed in place of the Russian Empire following the revolutions and civil war of 1917-1922. One of these flows occured in the city of Almaty in 1921, leading to significant damage, and another flow took place in the Adyr-Su valley in the Caucasus, destroying two mountaineering camps. Debris flows were studied in the Caucasus, the Carpathians, the mountains of Central Asia and Siberia, in Kamchatka Peninsula etc. Properties of debris flow mass were studied in laboratory (I.G. Esman), the most dangerous debris flow basins were surveyed and studied (A.F. Verzhbitsky), and protective measures for roads and infrastructure were designed (A.L. Brilinsky).

\section{4 "The golden decades" of the Soviet debris flow science}

The most active research started in the second half of the $20^{\text {th }}$ century, when construction in mountains became widespread.

In 1947-1991 a Debris Flow Commission under the auspices of the Russian Academy of Sciences and of the State committee on science and technology of the USSR Council of Ministers coordinated the debris flow research. It organised conferences, published proceedings and books on the state-of-the art. The Commission was chaired in different years by M.A. Velikanov, M.F. Sribny, S.M. Fleishman and Yu.B. Vinogradov. After a number of catastrophic debris flows, methods for debris flow studies were developed and manuals published, e.g. Churinov and Sheko [18], Rukovodstvo [19] etc. Assessment of debris flow hazards was introduced into the Construction norms and regulations [20] (fig. 2).

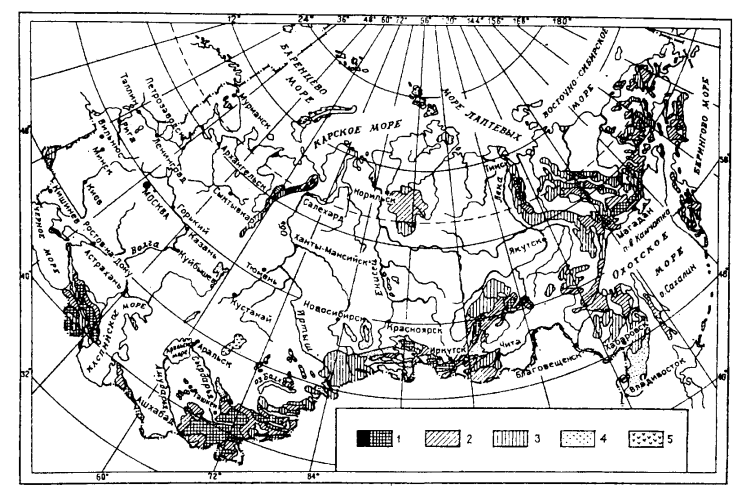

Figure 2: Sketch map of the debris flow danger in the USSR [20]. Degree of danger: 1 - high; 2 - average; 3 - low; 4 - potential danger; 5 - debris flow-like flows in arid areas and in the periphery of ice sheets.

24 debris flow conferences were organised in 1949-1982. The topics of conferences were wide ranging, from universal debris flow forums to meetings on specific questions such as: protection of rail roads; methods for study and 
forecast of debris flows, rockfalls and landslides; debris flow monitoring stations; measures against irrigation erosion and debris flows; methods of debris flow mapping; design of protective infrastructure.

The late 1950-80s can be considered "the golden thirty years" of the Soviet debris flow science. A strong 'Soviet school' of experts was formed. These worked in ministries, institutes, universities, science academies and hydrometeorological service. Debris flows in all territories of the USSR were studied, including: Azerbaidjan (I.I. Mechitov, B.A. Budagov, S.G. Rustamov), Armenia (I.V. Yegiazarov, V. Sanoyan, R.G. Asotryan, M.V. Tsovyan), Georgia (M.S. Gagoshidze, K.R. Begishvili, I.I. Kherkheulidze, G.M. Beruchashvili, V.I. Tevzadze, D.D. Tsereteli, E.D. Tsereteli, G.I. Kherkheulidze), Kazakhstan (Yu.B. Vinogradov, A.P. Gorbunov, A. Degovets, N.S. Dyurnbaum, S.P. Kavetsky, V.P. Mochalov, G.D. Rozhdestvensky, B.S. Stepanov, R.V. Khonin), Kyrgyzstan (M.I. Iveronova), Russia (I.V. Bogolyubova, A.V. Yermakov, E.V. Zaporozhchenko, V.Ye. Ioganson, V.K. Laperdin, V.F. Perov, I.B. Seynova, M.F. Sribny, Yu.B. Trzhcinsky, S.M. Fleishman, A.I. Sheko), Uzbekistan (F.K. Kocherga), Ukraine (M.M. Aizenberg, B.L. Velichko, B.M. Gol'din, B.N. Ivanov, A.N. Oliferov), Tadjikistan (I.A. Mossakovskaya, O.V. Tukeev, M.R. Yakutilov), Turkmenistan (N.M. Trofimov). This list is far from complete. The larger debris flow conferences attracted as many as 300 experts.

The designs developed in the USSR were used to build various constructions for protection against debris flows. Stations for debris flow monitoring and research were operating in Zailiysky Alatau, Caucasus, and in the Crimea.

In Kazakhstan a special organisation called Kazglavselezashchita was created to build protective constructions. These included dams on the Great and Little Almatinka, the rivers which on many occasions produced debris flows damaging the city of Almaty. In the 1970s experimental artificial debris flows were created in the Chemolgan River basin, as described by Vinogradov [21]. In Georgia a large dam was built to protect the town of Kvareli (fig. 3), where debris flows took over 200 lives in a hundred years. In the same region, meshlike protective constructions were built to protect the town of Telavi.

\section{Problems of late $20^{\text {th }}-$ early $21^{\text {st }}$ century}

The collapse of the USSR (1991) has divided the debris flow community by the new state boundaries. The Debris Flow Commission stopped to function. The economic crisis of the 1990s and abrupt fall in research funding were additional blows. The debris flow observations in Russia were practically ended. Many institutes stopped debris flow research.

Large debris flow disasters in the Caucasus at the turn of the millennia, such as catastrophic flows in the Gerkhozhan-Su river basin in 1999 (fig. 4) and 2000, numerous debris flows in June and a glacier disaster in September 2002 in the Genaldon river valley have attracted attention to this field again. Currently the debris flows in Russia are studied and monitored by such organisations as the 
Ministry for Emergency and Disaster Mitigation, regional geological monitoring offices, the Sevkavgiprovodkhoz Design and Planning Institute, Moscow State University, etc. New books in the field have been published, e.g. Chernomorets [22] and others. Debris flow expeditions are being arranged, and new publications are emerging. After a long interval, three conferences were organised in Russia in 2002-2005 [23, 24, 25].

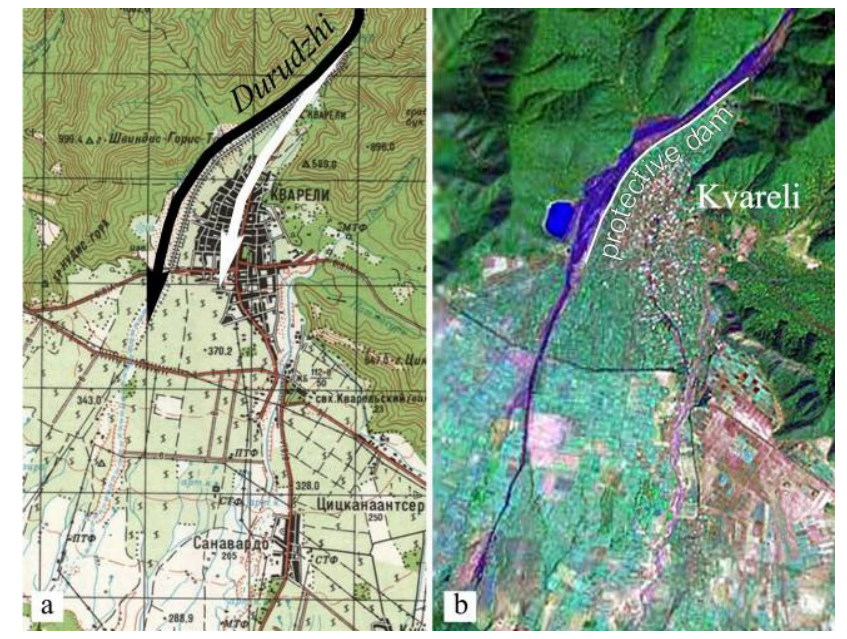

Figure 3: Dam protecting the town of Kvareli (Georgia) against debris flows. Arrow shows directions of debris flows before (white) and after (black) the construction. A - topographic map, b - Landsat ETM+ satellite image (C) MDA EarthSat, Google 2006).

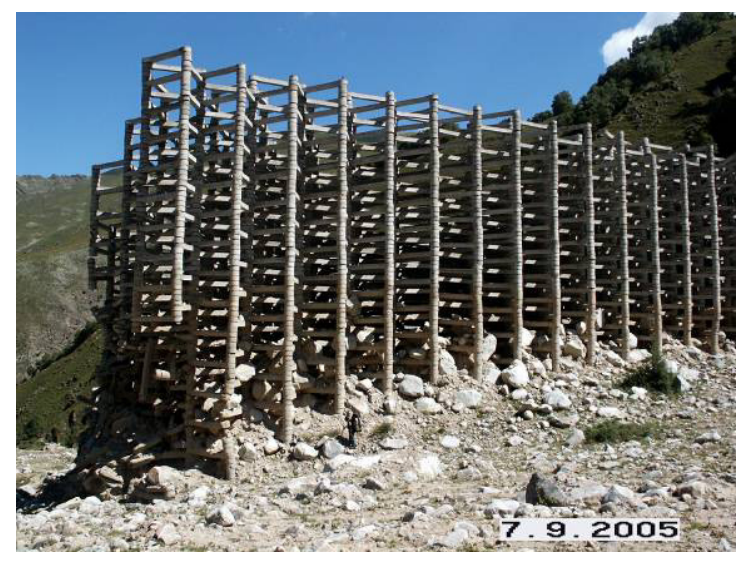

Figure 4: A reinforced-concrete mesh dam on the Gerkhozhan-Su River (North Caucasus, Russia), built in 1987-1999 and destroyed by a debris flow two months after completion. 
Nevertheless, the debris flow research community was not reunited until recently. Organisation and individual experts did not coordinate their work. The world debris flow conferences in recent years in San Francisco, Taipei and Davos have demonstrated that this science has considerably advanced in comparison to the contemporary state in the Soviet-Russian school. This in particular concerns such fields as field measurements of debris flow parameters, flow modelling, design and construction of protective structures.

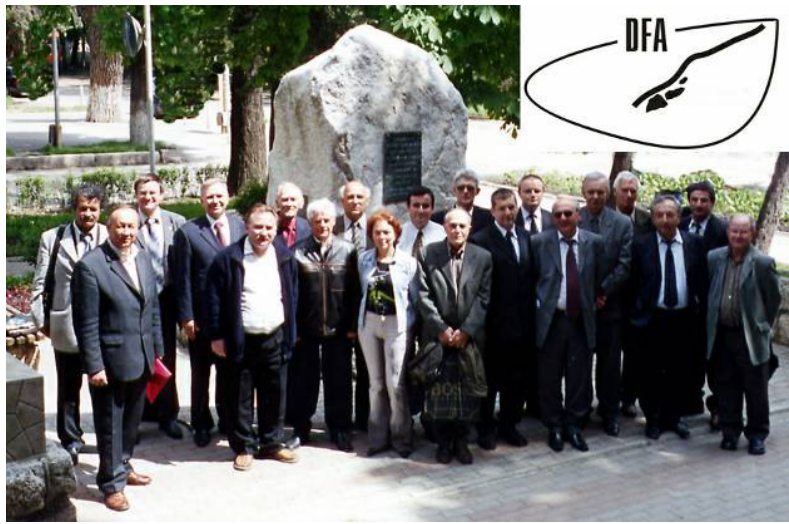

Figure 5: A group of the participants of the Debris Flow Association foundation meeting. Pyatigorsk, Russia, 17 May 2005. Top right: DFA logo.

\section{Debris Flow Association}

Recently the coordination of debris flow research in various organisations started to be perceived as an acute need. For several years, the reinstatement of the Debris Flow Commission was discussed. On the initiative of a group of experts (fig. 5), Debris Flow Association (DFA) was founded in Russia in 2005, as a professional society of experts (scientists and practitioners) for effecting and supporting activities in the field of debris flow/natural hazard studies, development of assessment and mitigation methods, and population protection. This society has now been joined by experts from Kazakhstan, Georgia, Azerbaidjan Armenia, and Canada. The DFA website is at: http://www.rsk.land.ru/index eng.htm.

Under the auspices of DFA, a Russian debris flow bibliography for 19682005 is being prepared for publication. About 1700 Russian works were published on this topic in 1850-1967, as listed by Vlasov and Krasheninnikova [26]. In the contemporary period (1968 - 2005), according to the estimates of A.Yu. Vlasov, over 3800 further Russian works were published.

It is planned to review and modernise the debris flow manuals. DFA has started the discussion on the creation of a large-scale state programme on the debris flow study and mitigation, which would enable to study the current state 
of the danger areas, educate new experts, create modern monitoring networks, improve forecasts and ensure the population safety. The DFA also plans to organise an international debris flow conference in Russian Caucasus in 2008.

\section{Acknowledgements}

Authors are grateful to I.V. Bondyrev and G.I. Kherkheulidze for valuable comments. This study has been supported by the Russian Foundation for Basic research, grant No 06-05-64787.

\section{References}

[1] Bogolyubova I.V. Selevye potoki i ikh rasprostranenie na territorii SSSR [Debris flows and their distribution in the USSR territory]. Leningrad: Gidrometeoizdat, 152 pp., 1957.

[2] Fleishman S.M. Seli [Debris flows]. Leningrad: Gidrometeoizdat, 312 pp., 1978.

[3] The Iliad by Homer. Translated by S. Butler. In: Project Gutenberg Online Book Catalog. http://www.gutenberg.org/etext/2199 Release Date 200006-01.

[4] Job 38:36-38. In: The Bible, New International Version. http:/www.biblegateway.com/passage/?book_id=22\&chapter=38\&verse $=$ 36\&end verse $=38 \&$ version $=31 \&$ context $=$ context 2006.

[5] Job 14:17-19 In: The Bible, New International Version. http:/www.biblegateway.com/passage/?book $\mathrm{id}=22 \&$ chapter $=14 \& v e r s e=$ $17 \&$ end verse $=19 \&$ version $=31 \&$ context $=$ context 2006 .

[6] The Letters of Pliny the Younger. Translated by W. Melmoth and edited by F.C.F. Bosanquest. In: Project Gutenberg Online Book Catalog. http://www.gutenberg.org/etext/2811 Release Date 2001-09-01.

[7] Seneca L. Annaei. Senecae naturales quaestiones. http://www.thelatinlibrary.com/sen/sen.qn.shtml

[8] Rustaveli S. The Knight in the Panther's Skin. Kroshka Books, 1999.

[9] Nart Sasrykva i devjanosto devjat jego bratjev: Abkhazskij narodnyi epos. Sukhumi, 1970.

[10] The Notebooks of Leonardo Da Vinci. Translated by J.P. Richter. In: Project Gutenberg Online Book Catalog. http://www.gutenberg.org/etext/5000 Release Date 2004-01-01.

[11] Fabre J.A. Essai sur la theorie des torrents et des rivieres. Paris, Chez Bidault, an V., 482 pp., 1797.

[12] Surrel A. Etude sur les torrents des Hautes-Alpes. Paris, 284 pp., 1841.

[13] The Geography of Strabo (eds. H.C. Hamilton, Esq., W. Falconer, M.A.). London: George Bell \& Sons. 1903.

[14] Pliny the Elder. The Natural History. John Bostock, M.D., F.R.S. H.T. Riley, Esq., B.A. London. Taylor and Francis, Red Lion Court, Fleet Street. 1855. 
[15] Pushkin A.S. The Caucasus. Translated by I. Zheleznova. http://learningrussian.com/library/pushkin/the\%20caucasus(1).htm.

[16] Statkowsky B. Project dorogi cherez khrebet Kavkazskikh gor mezhdu urochishem Kvishety I stantsiei Kobi [Project of a road trough the Caucasian Range between the Kvishety area and the Kobi station]. In: Zhurnal Glavnogo upravleniya putei soobsheniya I publichnukh zdaniy [Journal of the main bureau for transport routes and public buildings] (in Russian). Vol. 39, book 2-3, p. 249-282. 1859.

[17] Statkowsky B.I. O prichinakh proiskhozhdeniya Kazbekskogo zavala i merakh dlya ego preduprezhdeniya [Origin of Kazbek ice blockage and measures for its prevention]. Tiflis, 42 pp. 1877.

[18] Churinov, M.V, and Sheko, A.I. (eds) Metodicheskoye rukovodstvo po kompleksnomu izucheniju selei [Manual for comprehensive study of debris flows]. Moscow: Nedra, 159 pp. 1971.

[19] Rukovodstvo po izucheniyu selevykh potokov. [Manual for study of debris flows] Leningrad: Gidrometeoizdat, 144 pp. 1976.

[20] SNiP 2.01.01-82 Stroitelnye normy i pravila [Construction norms and regulations. Construction climatology and geophysics]. Official publication of the USSR state committee for construction. Moscow, 1983.

[21] Vinogradov Yu. B. Etyudy o selevykh potokakh [Etudes on debris flows]. Leningrad: Gidrometeoizdat, 144 pp. 1980.

[22] Chernomorets S.S. Origination sites of debris flow disasters: before and after. Moscow: Nauchny Mir, 184 p. 2005.

[23] Vserossiiskaya konferentsiya po selyam. Tezisy [Russian Debris Flow Conference. Abstracts]. October 8-11, 2002. Nalchik: VGI, 2002.

[24] Zashchita narodnokhozyaistvennykh objektov ot vozdeystviya selevykh potokov [Protection of the infrastructure objects from debris flows]. Proceedings of an International Debris Flow Conference, Pyatigorsk, 2003 November 17-21. Vol. 2. Pyatigorsk: Sevkavgiprovodkhoz, 175 pp. 2004.

[25] Vserossiiskaya konferentsiya po selyam. Tezisy [Russian Debris Flow Conference. Abstracts]. October 26-28, 2005. Nalchik: VGI, 2005.

[26] Vlasov A. Yu, Krasheninnikova N.V. Selevye yavleniya na territorii SSSR i mery bor'by $\mathrm{s}$ nimi. [Debris flows in USSR and protective measures]. Bibliography of literature issued in 1850 - 1967. Moscow: Moscow State Univ. Press, 216 pp. 1969. 